\title{
Penerapan Metode Sugesti-Imajinatif dengan Menggunakan Media Gambar Fotografi untuk Meningkatkan Kemampuan Menulis Karangan Deskripsi
}

\author{
Isroyati $^{(1)}$, Aliffia Teja Prasasty ${ }^{(2)}$, Fitri Senny Hapsari ${ }^{(3)}$ \\ 1,2 Universitas Indraprasta PGRI Jakarta 1, Indonesia \\ Email: ${ }^{1}$ kvivie24@gmail.com, ${ }^{2}$ aliffia8@gmail.com
}

\begin{abstract}
Abstrak: Masalah yang diteliti yaitu menguji keefektifan metode sugesti-imajinatif dengan media gambar fotografi dalam menulis karangan deskripsi dengan menggunakan metode sugestiimajinasi dan media gambar fotografi. Tujuan penelitian ini adalah mengetahui (1) keefektifan Metode sugesti-imajinatif dengan media gambar fotografi dalam meningkatkan keterampilan menulis karangan deskripsi, (2) hasil belajar siswa dalam menulis karangan deskripsi dengan menggunakan metode-sugesti imajinatif dengan media gambar fotografi.Metode penelitian yang digunakan adalah metode eksperimen dengan menggunakan desain kelas kontrol pretes-postes berpasangan yang dilakukan di SMK Dwiguna Depok tahun pelajaran 2019/2020. Sedangkan teknik yang digunakan untuk menarik
\end{abstract}

\begin{tabular}{l}
\hline Tersedia Online di \\
\hline http://journal.unublitar.ac.id/pendidi \\
\hline kan/index.php/Riset_Konseptual \\
\hline Sejarah Artikel \\
\hline Diterima pada : 27-04-2021 \\
Disetuji pada : 29-04-2021 \\
Dipublikasikan pada : 30-04-2021 \\
Kata Kunci: \\
Metode Sugesti-Imaginatif, Media Gambar \\
Fotografi, Menulis, Karangan Deskripsi \\
DOI: \\
\hline http://doi.org/10.28926/riset_konseptual.v5i \\
2.353
\end{tabular}

kesimpulan hasil penelitian ini adalah teknik pemberian tes, observasi, dan angket. Hasil uji hipotesis menunjukan penerapan metode sugesti-imajinatif dengan media gambar fotografi secara signifikan dapat lebih meningkatkan kemampuan menulis karangan deskripsi siswa dibandingkan dengan pembelajaran dengan metode metode konvensional. Ini dibuktikan berdasarkan perhitungan statistik untuk data postes kelas eksperimen dan kelas kontrol, thitung yang didapat yaitu diperoleh thitung sebesar 9,38 dan dengan menggunakan taraf signifikan 0,05 (tingkat kepercayaan 95\%) serta derajat kebebasan 58 diperoleh $\mathrm{t}$ tabel sebesar 2.00 terbukti $\mathrm{t}$ hitung $(9,38)>\mathrm{t}$ tabel $(2,00)$. Karena $\mathrm{t}$ hitung $>\mathrm{t}$ tabel, maka dapat dikatakan bahwa perlakuan yang diberikan pada kelas eksperimen memberikan hasil yang lebih baik dibandingkan dengan hasil kelas kontrol.

\section{PENDAHULUAN}

Dalam dunia pendidikan dikenal macam-macam pengajaran, di antaranya adalah pengajaran bahasa. Bahasa merupakan alat komunikasi yang penting dalam kehidupan. Oleh karena itu, pembelajaran bahasa diarahkan agar siswa terampil berkomunikasi, baik lisan maupun tulisan.

Dalam pengajaran bahasa Indonesia kita jumpai empat aspek kegiatan berbahasa, yaitu mendengarkan, berbicara, membaca, dan menulis. Empat aspek ini tidak dapat dipisahkan satu dengan yang lainnya. Salah satu aspek keterampilan berbahasa yang harus dikuasai siswa adalah menulis. Menulis merupakan suatu kegiatan memindahkan bahasa lisan ke dalam bentuk tulisan dengan menggunakan lambang-lambang grafem. Oleh sebab itu, tidak mungkin orang akan lancar menulis jika tidak memiliki keterampilan tulis. 
Menurut Zainurrahman (2011:2) menulis merupakan salah satu keterampilan yang tidak dikuasai oleh setiap orang, apalagi menulis dalam konteks akademik (academic writing), seperti menulis esai, karya ilmiah, laporan penelitian, dan sebagainya. Di antara keempat keterampilan tersebut, yang dianggap membutukan penguasaan keterampilan paling tinggi adalah keterampilan berbahasa dalam bidang menulis. Walaupun menulis merupakan keterampilan yang paling akhir, tetapi pada kenyataannya menulis merupakan keterampilan yang membutuhkan berbagai macam aspek, antara lain aspek penguasaan kosakata sebagai faktor intrinsik yang mendukung keterampilan menulis.

Menulis merupakan salah satu bentuk berkomunikasi secara tidak langsung, tidak secara tatap muka dengan orang lain, dan merupakan suatu kegiatan produktif dan ekspresif. Sehubungan dengan hal ini, mengutip pendapat Moorsey (Syihabbudin 2009:249) mengungkapkan bahwa: menulis dipergunakan oleh orang terpelajar untuk mencatat/merekam, meyakinkan, melaporkan/memberitahukan, memengaruhi, maksud seperti tujuan itu hanya dapat dicapai dengan baik oleh orang-orang yang dapat menyusun pikirannya dapat mengutarakannya dengan jelas. Kejelasan ini tergantung pada pikiran, organisasi, pemakaian kata-kata, dan struktur kalimat.

Sebagaimana juga dikemukakan oleh Tarigan (2008:22) mengatakan bahwa pada prinsipnya fungsi utama dari menulis adalah sebagai alat komunikasi yang tidak langsung. Menulis sangat penting bagi pendidikan karena memudahkan para pelajar berpikir, juga dapat menolong kita berpikir secara kritis, dan memudahkan kita merasakan dan menikmati hubungan-hubungan, memperdalam daya tanggap atau persepsi kita, memecahkan masalah-masalah yang kita hadapi, menyusun urutan bagi pengalaman. Menulis dapat membantu kita menjelaskan pikiran-pikiran kita. Tidak jarang kita menemui apa yang sebenarnya kita pikirkan dan rasakan mengenai orangorang, gagasan-gagasan, masalah-masalah, dan kejadian-kejadian hanya dalam proses menulis yang aktual. Salah satu dari tugas-tugas terpenting penulis sebagai penulis adalah menguasai prinsip-prinsip menulis dan berpikir, yang akan dapat menolongnya mencapai maksud dan tujuannya. Yang paling penting di antara prinsipprinsip yang dimaksud itu adalah penemuan, susunan, dan gaya. Secara singkat: belajar menulis adalah belajar berpikir dalam/dengan cara tertentu.

Menulis merupakan kegiatan yang produktif dan ekspresif sehingga keterampilan ini tidak datang dengan sendirinya akan tetapi membutuhkan latihan dan kebiasaan yang berkesinambungan atau terus menerus dibina. Menulis adalah cara berpikir teratur yang diungkapkan dalam bahasa tulis. Keterampilan seseorang untuk mengungkapkan ide, pikiran, gagasan, pengetahuan, ilmu, dan pengalaman merupakan suatu keterampilan yang produktif.

Dalam keterampilan menulis dikenal ada lima jenis, yaitu menulis deskripsi, narasi, eksposisi, argumentasi dan persuasi. Dari kelima jenis menulis tersebut yang menarik untuk penulis teliti adalah keterampilan menulis deskripsi. Keterampilan menulis deskripsi memang menjadi satu keterampilan berbahasa yang sulit untuk dikuasai. Hal ini disebabkan adanya unsur yang harus dikuasai oleh penulis, yaitu unsur bahasa, seperti ejaan, struktur kalimat, kohesi, koherensi, serta unsur nonbahasa yang dijadikan ide atau gagasan dalam sebuah tulisan yang meliputi pengetahuan dan pengalaman penulis.

Selain itu, banyak guru mengalami kesulitan untuk membiasakan anak belajar menulis. Penyebabnya adalah kesalahan dalam hal pengajaran yang terlalu kaku sehingga menimbulkan kesan bahwa menulis itu sulit. Ditambah pula dengan banyaknya guru yang belum memahami pentingnya keterampilan menulis. Belum banyak dari mereka yang bisa menyuguhkan materi pelajaran dengan cara yang tepat dan menarik. Maka dari itu, wajar jika siswa pun akhirnya tidak mampu dan tidak menyukai pelajaran menulis. Masalah lain adalah siswa sulit menentukan pilihan kata, menggabungkan kalimat, dan menuangkan ide dalam tulisan deskripsi. Kesulitan ini menyebabkan rendahnya kualitas tulisan siswa baik pada aspek isi maupun 
kebahasaan. Maka dari itu, penggunaan metode sangat penting kehadirannya dalam pelajaran.

Untuk menunjang keberhasilan pengajaran bahasa Indonesia terutama menulis dan mencapai hasil optimal, maka perlu diperhatikan faktor intrinsik dan faktor ekstrinsik yang ada pada siswa. Faktor intrinsik di antaranya, motivasi belajar, bakat, persepsi diri dan lain-lain. Fakor ekstrinsik yakni media pembelajaran dan metode pembelajaran.

Menurut Heinrich dalam Daryanto (2010:4) kata "media" merupakan bentuk jamak dari kata "medium". Medium dapat didefinisikan sebagai perantara atau pengantar terjadinya komunikasi dari penerimaan. Media merupakan salah satu komponen komunikasi, yaitu sebagai pembawa pesan dari komunikator menuju komunikan. Berdasarkan definisi tersebut, dapat dikatakan bahwa proses pembelajaran merupakan proses komunikasi. Secara umum, media adalah semua bentuk perantara yang dipakai orang sebagai penyebar ide/gagasan itu pada penerima. Secara lebih khusus, pengertian media dalam proses belajar-mengajar cenderung diartikan sebagai alat-alat grafik photografis atau elektronik untuk menangkap, memproses, dan menyusun kembali informasi visual atau verbal.

Media adalah perantara atau pengantar pesan dari pengirim ke penerima pesan media juga dapat dikatakan sebagai sesuatu yang dapat digunakan untuk menyalurkan pesan dari pengirim ke penerima sehingga dapat merangsang pikiran, perasaan, perhatian, dan minat serta perhatian siswa sedemikian rupa sehingga proses belajar terjadi. Dari pengertian tersebut dapat diketahui bahwa media itu sangat penting digunakan dalam proses pembelajaran karena dengan media pembelajaran akan berjalan lebih efektif dan menarik. Dari berbagai uraian di atas dapat disimpulkan bahwa media pembelajaran adalah segala sesuatu yang dapat digunakan untuk menyalurkan pesan dan membantu mempertegas bahan pelajaran sehingga dapat merangsang pikiran, perasaan, perhatian, dan minat siswa dalam proses belajar. Diharapkan dengan penggunaan media dalam proses pembelajaran siswa akan lebih kreatif dan inovatif dalam keterampilan menulis.

Ada beberapa alasan dibutuhkannya media pembelajaran di antaranya sebagai berikut: guru harus berusaha menyedikan materi yang mudah diserap siswa, materi menjadi lebih mudah dimengerti apabila menggunakan alat bantu, proses belajar mengajar memerlukan media dalam hal ini disebut media pembelajaran.

Sebagaimana dikemukakan oleh Subana (2009:291) dalam memilih media harus menyebutkan kriterianya, yaitu: ketepatan dengan tujuan pengajaran; dukungan terhadap isi bahan pengajaran; memberikan kemudahan; keterampilan guru dalam menggunakan waktu; sesuai dengan taraf berfikir siswa.

Media pembelajaran yang digunakan guru harus sesuai dengan tujuan pembelajaran yang telah direncanakan sehingga merangsang dan menumbuhkan minat siswa dalam belajar. Dengan demikian akan terjalin interaksi antara media pembelajaran dan siswa pada akhirnya akan mampu mempercepat proses pemahaman siswa terhadap isi pembelajaran.

Metode pembelajaran mempunyai peranan penting dalam proses belajar mengajar. Salah satunya adalah metode pembelajaran sugesti-imajinatif yang diadaptasi dari metode pembelajaran sugestopedia. Metode sugesti-imajinatif adalah metode yang bertujuan untuk merangsang daya pikir siswa dalam pembelajaran terutama dalam pembelajaran karangan menulis deskripsi yang menjadi salah satu variable yang diteliti penulis.

Menurut Semi (2007: 53) tulisan atau teks deskripsi ialah tulisan yang tujuannya untuk memberikan rincian atau detail tentang objek sehingga dapat memberi pengaruh pada emosi dan menciptakan imajinasi pembaca bagaikan melihat, mendengar, atau merasakan langsung apa yang disampaikan penulis.

Rumusan itu memperhatikan bahwa deskripsi merupakan karya tulisan eksposisi yang disajikan dengan menekankan kepada detail sehingga ia bagaikan fotokopi objek yang digambarkan. Deskripsi umumnya menggambarkan tentang 
sesuatu yang dapat diindra. Oleh sebab itu, pada umumnya, objeknya berupa alam, benda, tempat suasana, dan manusia.

Salah satu media yang dapat digunakan untuk pembelajaran menulis karangan deskripsi adalah media gambar fotografi. Media gambar merupakan media visual dua dimensi di atas bidang yang tidak transparan (Subana, 2011: 322). Lebih rinci Daryanto (2010:108) menjelaskan bahwa gambar fotografi merupakan salah satu media pengajaran yang amat dikenal di dalam setiap kegiatan pembelajaran. Hal itu disebabkan kesederhanaannya, tanpa memerlukan perlengkapan, dan tidak perlu diproyeksikan untuk mengamatinya. Gambar fotografi itu pada dasarnya membantu mendorong para siswa dan dapat mengembangkan minatnya pada pembelajaran Dengan demikian, media gambar dapat digunakan untuk memberikan gambaran tentang sesuatu sehingga penjelasannya lebih konkret daripada diuraikan dengan kata-kata.

Lebih lanjut Metode sugesti-imajinatif mengambil adaptasi dari metode sugestopedia. Menurut Tarigan (2009:93) sugesti adalah jantung sugestopedia. Dalam banyak hal dan bagi banyak orang, sugesti justru menyulap visi (daya lihat/penglihatan) tatapan yang tajam, buaian pandangan sayu, dan perintah-perintah sang hipnotis yang diulang secara monoton. Lebih lanjut Lozanov menuntut serta menegaskan bahwa yang membedakan metodenya dari hipnotis dan bentuk-bentuk pengawasan pikiran dan ingatan lainnya ialah bahwa bentuk-bentuk lain tersebut kekurangan "rasa desugestif-sugestif" (desuggestive-suggestivesense) dan gagal menciptakan suatu pendirian yang konstan yang dicadangkan melalui psiko-relaksasi yang konsentratif Lozanov dalam Tarigan (2009:94).

Dalam metode ini diasumsikan bahwa relaksasi merupakan teknik yang tepat untuk digunakan. Suasana yang dapat memberi sugesti, seperti alunan musik yang terdengar sayup-sayup, dekorasi ruangan yang menarik, dan tempat duduk yang menyenangkan sangat berperan penting. Metode ini menekankan sugesti kepada peserta didik agar mereka memiliki kepercayaan diri. Sikap dan prilaku guru di dalam kelas adalah salah satu kunci yang menjamin keberhasilan sebuah sugesti.

Pada prinsipnya, metode sugesti-imajinatif ini dilakukan dengan cara memberi sugesti untuk merangsang daya imajinasi siswa. Dengan metode sugestif-imajinatif, lagu tidak hanya digunakan untuk menciptakan suasana sugestif, stimulus, dan sekaligus menjadi jembatan bagi siswa untuk membayangkan atau menciptakan gambaran dan kejadian berdasarkan tema lagu. Respons yang diharapkan muncul dari pakar para siswa berupa kemampuan melihat gambar-gambar kejadian tersebut dengan imajinasi-imajinasi dan logika yang dimiliki lagu mengungkapkan kembali dengan menggunakan simbol-simbol verbal.

Berdasarkan tingkat kesulitan menulis karangan deskriptif yang kompleks tentulah diperlukan media dan model pembelajaran yang tepat sesuai dengan kriteria penguasaan kemampuan menulis karangan tersebut. Berdasarkan definisi dan pemanfaatan metode sugesti imaginatif, maka penulis merasa perlu untuk mengadakan penelitian mengenai karangan deskripsi melalui metode sugesti-imajinatif dengan bantuan media gambar fotografi. Dengan demikian, diharapkan melalui penelitian ini dapat memberikan kontribusi bagi dunia pengajaran terutama dalam pembelajaran menulis karangan deskripsi. Selain itu pula, dengan adanya penelitian ini diharapkan dapat membantu siswa dan guru untuk menciptakan suasana pembelajaran menulis yang lebih menarik dan kreatif. Seperti penelitian yang pernah dilakuka oleh Huda, Muhammad Mishbakhul. (2019) dengan judul "Keefektifan Pembelajaran Menulis Cerita Pendek dengan Model Kreatif Produktif dan Model Sugesti Imajinasi Berdasarkan Kreativitas Verbal pada Peserta Didik Kelas XI SMK" yang berpengaruh positif terhadap peningkatan kualitas pembelajaran menulis cerita pendek. 


\section{METODE}

Metode yang digunakan dalam penelitian ini adalah metode eksperimen dengan desain "pretest, posttest control group design" (sugiyono. 2010:112). Subjek penelitian ini dibagi menjadi dua kelompok, yaitu kelompok eksperimen dan kelompok kontrol. Untuk kelompok eksperimen, diberikan perlakuan khusus yaitu pembelajaran menulis karangan deskripsi dengan metode sugesti-imajinatif dengan media gambar fotografi yang telah diberikan tes awal (pretest) sebelumnya dan menguji keberhasilan perlakuan dengan memberikan tes akhir (posttest) terhadap kelompok tersebut. Sementara itu, kelas kontrol diberikan pembelajaran menulis karangan deskripsi dengan metode ceramah.

Populasi adalah keseluruhan subjek penelitian (Arikunto, 2006:130). Populasi dalam penelitian ini adalah seluruh siswa kelas X SMK Dwiguna Depok tahun pelajaran 2019/2020 yang terdiri atas 5 kelas. Sampel adalah sebagian atau wakil populasi yang diteliti. Dinamakan penelitian sampel apabila kita bermaksud untuk menggeneralisasikan hasil penelitian (Arikunto, 2006:131).

Sampel dalam penelitian ini terdiri dari dua kelas, yaitu kelas kontrol dan kelas eksperimen, dalam menentukan kelas eksperimen dan kelas kontrol peneliti melakukan secara acak undi kelas (random). Berdasarkan hasil undian tersebut, yang akan di jadikan adalah kelas RPL. 1 untuk kelas eksperimen berjumlah 30 siswa dan kelas AP. 2 untuk kelas kontrol berjumlah 30 siswa. Dengan demikan, di SMK Dwiguna Depok terdapat sejumlah 60 siswa dengan perincian 30 siswa kelas eksperimen dan 30 siswa kelas kontrol.

Teknik pengumpulan data yang dilakukan dalam penelitian ini adalah teknik tes, angket, dan observasi. Kemudian pengolahan data dilaksanakan setelah kegiatan pengumpulan data selesai. Data yang terkumpul berupa hasil pretes dan postes keterampilan menulis karangan deskripsi di kelas eksperimen dan di kelas kontrol. Kegiatan menganalisis karangan dilakukan untuk memberikan gambaran keberhasilan siswa dalam menulis karangan deskripsi. Analisis karangan meliputi aspek kebahasaan yang terdiri dari aspek isi, organisasi karangan, kosakata, dan penggunaan bahasa/EYD.

Adapun langkah-langkah yang penulis lakukan dalam pengolahan data dengan menggunakan rumus-rumus statistik adalah sebagai berikut.

Mengolah skor pretes dan postes siswa di kelas kontrol dan kelas eksperimen yang diberikan oleh ketiga penimbang menjadi nilai dengan rumus:

$\mathrm{N}=(\mathrm{STS}: \mathrm{STI}) \mathrm{X} \mathrm{SN}$

Keterangan:

$\mathrm{N}$ : Nilai

STS: Skor Total Siswa

STI: Skor Total Ideal

SN : Standar Nilai

Kemudian melakukan uji reliabilitas antarpenimbang. Teknik analisis ini digunakan untuk ujian-ujian yang dilakukan oleh lebih dari satu orang penimbang bagi setiap testi (Sugiyono, 2010: 116-117). Uji reliabilitas ini didasarkan pada skor yang telah diolah menjadi nilai dengan menggunakan prinsip ANAVA yang dilakukan dengan langkah terakhir yaitu melakukan uji normalitas dengan rumus chi kuadrat $\left(\mathrm{X}^{2}\right)$.

Instrument Tes tidak lain adalah suatu set stimuli yang diberikan kepada subjek atau objek yang hendak diteliti. Sudjana (2005:35) mengungkapkan bahwa tes sebagai alat penilaian adalah pertanyaan-pertanyaan atau latihan yang diberikan kepada siswa untuk mendapat jawaban dari siswa dalam bentuk lisan (tes lisan), dalam bentul tulisan (tes tulisan), atau dalam bentuk perbuatan (tes tindakan).

Tes yang digunakan dalam penelitian ini adalah tes tulisan. Tes tulisan digunakan untuk mengukur keterampilan siswa dalam menulis sebuah karangan deskripsi. Tes dilakukan sebanyak dua kali, yakni sebelum mendapat perlakuan (pretest) dan sesudah mendapat perlakuan (posttest). 
Kegiatan pembelajaran dengan metode sugesti-imajinatif dilakukan melalui media lagu dalam pembelajran menulis karangan deskripsi dilakukan mengacu pada perencanaan pembelajaran yang sebelumnya telah disusun berupa RPP. Evaluasi terhadap pelaksanaan dan pencapaian tujuan pembelajaran media dengan metode sugesti-imajinatif dengan media gambar fotografi menjadi tahap terakhir dari kegiatan pembelajaran menulis karangan deskripsi.

\section{HASIL dan PEMBAHASAN}

Penelitian dilaksanakan dalam tiga kali pertemuan, alokasi waktu untuk setiap pertemuan adalah $2 \times 45$ menit. Pertemuan pertama dilaksanakan pada tanggal 6 Agustusi 2019 pada pertemuan tersebut penulis mengadakan tes awal (pretes) di kelas $X$ AP dan di kelas X RPL dengan jumlah siswa masing-masing kelas sebanyak 30 siswa. Pertemuan kedua dilaksanakan pada pada tanggal 10 Agustus 2019 penulis memberikan perlakuan berupa pembelajaran menulis dengan menggunakan metode sugesti-imajinatif dengan media gambar fotografi terhadap siswa kelas X RPL. Adapun pertemuan ketiga pada tanggal 13 Agustus 2019 digunakan penulis untuk mengadakan postes dalam rangka mengukur kemampuan akhrir siswa dalam pembelajaran menulis setelah diberi perlakuan, kegiatan ini masih dilaksanakan dalam kelas yang sama dan jumlah siswa yang sama pula.

Pada akhir pelaksanaan penelitian, penulis memperoleh data berupa data primer dan data sekunder. Data sekunder merupakan hasil lembar angket yang diisi oleh siswa serta hasil observasi yang diisi oleh dua orang observer untuk mengamati dan menilai ketika proses belajar mengajar berlangsung, sedangkan data primer merupakan hasil tes perbuatan, yaitu siswa menulis karangan deskripsi yang diungkapkan lewat tulisan sebanyak dua kali, yaitu pretes dan postes. Untuk memperkecil unsur subjektifitas dalam pemberian nilai, kedua tes tersebut telah diamati olah dua orang penilai dan menghasilkan skor keterampilan menulis dari masing-masing siswa.

Adapun skor pretes dan postes keterampilan menulis karangan deskripsi siswa di kelas eksperimen dapat dilihat pada tabet berikut.

Tabel 1. Skor Pretes Menulis Karangan Deskripsi Kelas Eksperimen

\begin{tabular}{|c|c|c|c|c|c|c|c|c|c|c|c|c|c|c|}
\hline \multirow[b]{2}{*}{ No } & \multirow[b]{2}{*}{ Nama } & \multicolumn{7}{|c|}{ Peniai I } & \multicolumn{5}{|c|}{ Penilai II } & \multirow{2}{*}{$\begin{array}{c}\text { Rata } \\
\text { - } \\
\text { Rata }\end{array}$} \\
\hline & & I & 0 & Kk & $\mathbf{P}$ & $\mathbf{M}$ & Jml & I & OI & Kk & PB & $\mathbf{M}$ & Jml & \\
\hline \multirow[t]{2}{*}{1} & 2 & 3 & $\mathbf{I}$ & 5 & B & 7 & 8 & 9 & 10 & 11 & 12 & 1 & 14 & Skor \\
\hline & & & 4 & & 6 & & & & & & & 3 & & 15 \\
\hline \multirow[t]{2}{*}{1} & Aditya & 2 & 1 & 16 & 1 & 3 & 73 & 2 & 18 & 16 & 17 & 3 & 73 & 73 \\
\hline & Rahman & 0 & 7 & & 7 & & & 0 & & & & & & \\
\hline \multirow[t]{2}{*}{2} & Arfat Wijaya & 2 & 1 & 15 & 1 & 3 & 75 & 2 & 17 & 16 & 17 & 3 & 76 & 75 \\
\hline & & 3 & 7 & & 7 & & & 3 & & & & & & \\
\hline \multirow[t]{2}{*}{3} & Astri Apriiani & 2 & 1 & 12 & 1 & 3 & 77 & 2 & 19 & 16 & 17 & 3 & 75 & 76 \\
\hline & & 5 & 7 & & 5 & & & 6 & & & & & & \\
\hline
\end{tabular}




\begin{tabular}{|c|c|c|c|c|c|c|c|c|c|c|c|c|c|c|}
\hline \multirow[t]{2}{*}{4} & \multirow[t]{2}{*}{ Baskoro } & 2 & 1 & \multirow[t]{2}{*}{17} & 1 & \multirow[t]{2}{*}{3} & \multirow[t]{2}{*}{77} & \multirow{2}{*}{$\begin{array}{l}2 \\
4\end{array}$} & \multirow[t]{2}{*}{18} & \multirow[t]{2}{*}{15} & \multirow[t]{2}{*}{18} & \multirow[t]{2}{*}{3} & \multirow[t]{2}{*}{78} & \multirow[t]{2}{*}{77} \\
\hline & & 4 & 0 & & 5 & & & & & & & & & \\
\hline \multirow[t]{2}{*}{5} & Erni D & 2 & 1 & 17 & 1 & 3 & 74 & 1 & 18 & 16 & 17 & 3 & 72 & 73 \\
\hline & & 0 & 9 & & 6 & & & 9 & & & & & & \\
\hline \multirow[t]{2}{*}{6} & Fachri H & 1 & 1 & 15 & 1 & 3 & 69 & 1 & 16 & 15 & 15 & 3 & 68 & 69 \\
\hline & & 8 & 7 & & 6 & & & 9 & & & & & & \\
\hline \multirow[t]{2}{*}{7} & Fina $\mathrm{T}$ & 1 & 1 & 15 & 1 & 3 & 69 & 2 & 16 & 15 & 15 & 3 & 69 & 69 \\
\hline & & 9 & 6 & & 6 & & & 0 & & & & & & \\
\hline \multirow[t]{2}{*}{8} & Govinda & 2 & 1 & 16 & 1 & 3 & 71 & 2 & 17 & 15 & 15 & 3 & 72 & 72 \\
\hline & & 0 & 6 & & 6 & & & 1 & & & & & & \\
\hline \multirow[t]{2}{*}{9} & Hadi S & 2 & 1 & 15 & 1 & 3 & 70 & 2 & 16 & 16 & 16 & 3 & 71 & 71 \\
\hline & & 0 & 6 & & 6 & & & 0 & & & & & & \\
\hline \multirow[t]{2}{*}{10} & Herman C & 2 & 1 & 17 & 1 & 4 & 80 & 2 & 20 & 16 & 16 & 4 & 82 & 81 \\
\hline & & 5 & 9 & & 6 & & & 6 & & & & & & \\
\hline \multirow[t]{2}{*}{11} & Ika A & 1 & 1 & 15 & 1 & 3 & 70 & 2 & 16 & 15 & 17 & 3 & 70 & 70 \\
\hline & & 9 & 7 & & 6 & & & 0 & & & & & & \\
\hline \multirow[t]{2}{*}{12} & Iklimah & 2 & 1 & 17 & 1 & 3 & 81 & 2 & 18 & 17 & 15 & 3 & 77 & 79 \\
\hline & & 3 & 9 & & 9 & & & 2 & & & & & & \\
\hline \multirow[t]{2}{*}{13} & Marpuah & 1 & 1 & 15 & 1 & 3 & 68 & 2 & 16 & 15 & 18 & 3 & 69 & 68 \\
\hline & & 8 & 6 & & 6 & & & 0 & & & & & & \\
\hline \multirow[t]{2}{*}{14} & Muh Altur & 2 & 2 & 18 & 1 & 4 & 84 & 2 & 18 & 16 & 15 & 4 & 82 & 83 \\
\hline & & 5 & 0 & & 7 & & & 6 & & & & & & \\
\hline \multirow[t]{2}{*}{15} & Muh. Nur I & 1 & 1 & 15 & 1 & 3 & 70 & 2 & 16 & 15 & 18 & 3 & 70 & 70 \\
\hline & & 9 & 7 & & 6 & & & 0 & & & & & & \\
\hline \multirow[t]{2}{*}{16} & Nita $E$ & 2 & 1 & 17 & 1 & 3 & 79 & 2 & 19 & 16 & 16 & 3 & 80 & 79 \\
\hline & & 5 & 0 & & 6 & & & 4 & & & & & & \\
\hline \multirow[t]{2}{*}{17} & Niar F & 1 & 1 & 15 & 1 & 3 & 69 & 1 & 15 & 16 & 17 & 3 & 69 & 69 \\
\hline & & 9 & 6 & & 6 & & & 9 & & & & & & \\
\hline \multirow[t]{2}{*}{1} & 2 & 3 & 4 & 5 & 6 & 7 & 8 & 9 & 10 & 11 & 12 & 1 & 14 & 15 \\
\hline & & & & & & & & & & & & 3 & & \\
\hline
\end{tabular}

$\begin{array}{lllllllllllllll}18 & \text { Nova F } & 1 & 1 & 15 & 1 & 3 & 71 & 1 & 16 & 16 & 15 & 3 & 71 & 71\end{array}$ 


\begin{tabular}{|c|c|c|c|c|c|c|c|c|c|c|c|c|c|c|}
\hline & & 9 & 7 & & 7 & & & 9 & & & & & & \\
\hline \multirow[t]{2}{*}{19} & Raihan F & 1 & 1 & 15 & 1 & 3 & 70 & 1 & 16 & 15 & 16 & 3 & 69 & 69 \\
\hline & & 9 & 7 & & 6 & & & 9 & & & & & & \\
\hline \multirow[t]{2}{*}{20} & Riansah F & 2 & 1 & 16 & 1 & 3 & 73 & 2 & 17 & 16 & 16 & 3 & 72 & 72 \\
\hline & & 0 & 7 & & 7 & & & 0 & & & & & & \\
\hline \multirow[t]{2}{*}{21} & Sam A & 2 & 1 & 16 & 1 & 3 & 71 & 2 & 16 & 15 & 17 & 3 & 71 & 71 \\
\hline & & 0 & 7 & & 8 & & & 1 & & & & & & \\
\hline \multirow[t]{2}{*}{22} & Sahraj R & 2 & 1 & 16 & 1 & 3 & 71 & 2 & 18 & 16 & 17 & 3 & 74 & 72 \\
\hline & & 0 & 6 & & 6 & & & 0 & & & & & & \\
\hline \multirow[t]{2}{*}{23} & Sigit & 2 & 1 & 16 & 1 & 3 & 73 & 2 & 17 & 15 & 17 & 3 & 72 & 72 \\
\hline & & 0 & 7 & & 7 & & & 0 & & & & & & \\
\hline \multirow[t]{2}{*}{24} & Syamsul R & 2 & 1 & 16 & 1 & 3 & 74 & 1 & 18 & 16 & 17 & 3 & 73 & 73 \\
\hline & & 0 & 8 & & 7 & & & 9 & & & & & & \\
\hline \multirow[t]{2}{*}{25} & Soleh D & 2 & 1 & 15 & 1 & 3 & 72 & 2 & 17 & 16 & 17 & 3 & 73 & 72 \\
\hline & & 0 & 7 & & 7 & & & 0 & & & & & & \\
\hline \multirow[t]{2}{*}{26} & Tri W & 2 & 1 & 16 & 1 & 3 & 75 & 2 & 17 & 16 & 17 & 3 & 74 & 74 \\
\hline & & 3 & 6 & & 7 & & & 4 & & & & & & \\
\hline \multirow[t]{2}{*}{27} & Widya & 1 & 1 & 15 & 1 & 3 & 69 & 1 & 16 & 15 & 16 & 3 & 69 & 69 \\
\hline & & 9 & 6 & & 6 & & & 9 & & & & & & \\
\hline \multirow[t]{2}{*}{28} & Wiwit S & 2 & 1 & 15 & 1 & 3 & 74 & 2 & 17 & 16 & 17 & 3 & 74 & 74 \\
\hline & & 1 & 8 & & 7 & & & 1 & & & & & & \\
\hline \multirow[t]{2}{*}{29} & Yahya W & 2 & 1 & 16 & 1 & 3 & 77 & 2 & 16 & 16 & 17 & 3 & 76 & 76 \\
\hline & & 3 & 8 & & 7 & & & 4 & & & & & & \\
\hline \multirow[t]{4}{*}{30} & Zahra M & 2 & 1 & 17 & 1 & 3 & 73 & 2 & 18 & 16 & 18 & 3 & 73 & 73 \\
\hline & & 1 & 7 & & 8 & & & 4 & & & & & & \\
\hline & Jumlah & & & & & & & & & & & & & 2193 \\
\hline & Nilai rata-rat & ean & & & & & & & & & & & & 73,06 \\
\hline $\begin{array}{l}\text { Kete } \\
\text { I } \\
\text { OI } \\
\text { Kk } \\
\text { PB } \\
\text { M }\end{array}$ & $\begin{array}{l}\text { angan: } \\
\text { : Isi } \\
\text { : Organisa } \\
\text { : Kosakata } \\
\text { : Penggun } \\
\text { : Mekanisn }\end{array}$ & $\mathrm{B}$ & nasa & & & & & & & & & & & \\
\hline
\end{tabular}


Tabel 2. Skor postes Keterampilan Menulis Deskripsi Siswa Kelas Eksperimen

\begin{tabular}{cccccccccccccc}
\hline & & \multicolumn{1}{c}{ Peniai I } & \multicolumn{11}{c}{ Penilai II } \\
\cline { 3 - 4 } & Nama & I & OI & Kk & PB & M & Jml & I & OI & Kk & PB & M & J \\
1 & 2 & 3 & 4 & 5 & 6 & 7 & 8 & 9 & 10 & 11 & 12 & 13 & I
\end{tabular}

Rata-

Rata

Skor

\begin{tabular}{|c|c|c|c|c|c|c|c|c|c|c|c|c|c|c|}
\hline \multirow[t]{2}{*}{1} & Aditya & 23 & 20 & 16 & 18 & 4 & 81 & 23 & 21 & 18 & 17 & 4 & 83 & 82 \\
\hline & \multicolumn{14}{|l|}{ Rahman } \\
\hline 2 & Arfat Wijaya & 24 & 20 & 17 & 17 & 4 & 81 & 23 & 20 & 17 & 19 & 4 & 83 & 82 \\
\hline 3 & Astri Apriiani & 28 & 20 & 19 & 19 & 4 & 90 & 28 & 23 & 18 & 20 & 4 & 93 & 91 \\
\hline 4 & Baskoro & 25 & 20 & 18 & 20 & 4 & 87 & 23 & 20 & 17 & 19 & 4 & 83 & 85 \\
\hline 5 & Erni D & 24 & 20 & 17 & 19 & 4 & 84 & 24 & 20 & 17 & 18 & 4 & 83 & 85 \\
\hline 6 & Fachri H & 22 & 17 & 15 & 16 & 2 & 72 & 20 & 18 & 16 & 17 & 3 & 74 & 73 \\
\hline 7 & Fina $T$ & 20 & 18 & 17 & 16 & 3 & 74 & 22 & 16 & 16 & 17 & 3 & 74 & 74 \\
\hline 8 & Govinda & 22 & 18 & 16 & 18 & 4 & 78 & 20 & 19 & 16 & 18 & 4 & 70 & 74 \\
\hline 9 & Hadi S & 23 & 19 & 17 & 18 & 4 & 81 & 21 & 19 & 17 & 19 & 4 & 80 & 80 \\
\hline 10 & Herman C & 28 & 20 & 18 & 23 & 5 & 94 & 29 & 20 & 18 & 23 & 5 & 95 & 95 \\
\hline 11 & Ika A & 21 & 18 & 17 & 19 & 4 & 79 & 20 & 18 & 17 & 19 & 4 & 78 & 78 \\
\hline 12 & Iklimah & 25 & 29 & 17 & 19 & 4 & 85 & 26 & 21 & 17 & 20 & 4 & 88 & 86 \\
\hline 13 & Marpuah & 20 & 18 & 17 & 19 & 4 & 82 & 23 & 17 & 17 & 19 & 4 & 80 & 81 \\
\hline 14 & Muh Altur & 28 & 20 & 18 & 20 & 5 & 91 & 28 & 23 & 18 & 19 & 4 & 92 & 91 \\
\hline 15 & Muh. Nur I & 27 & 21 & 19 & 20 & 4 & 86 & 21 & 20 & 17 & 19 & 4 & 83 & 85 \\
\hline 16 & Nita $E$ & 27 & 29 & 17 & 23 & 4 & 90 & 26 & 24 & 18 & 20 & 4 & 92 & 91 \\
\hline 17 & Niar F & 23 & 16 & 17 & 16 & 3 & 75 & 24 & 19 & 18 & 29 & 4 & 84 & 79 \\
\hline 18 & Nova F & 20 & 19 & 17 & 17 & 4 & 77 & 19 & 18 & 17 & 18 & 4 & 76 & 76 \\
\hline 19 & Raihan F & 20 & 19 & 16 & 18 & 3 & 76 & 21 & 18 & 17 & 18 & 4 & 78 & 77 \\
\hline 20 & Riansah F & 23 & 30 & 17 & 19 & 4 & 83 & 24 & 20 & 18 & 19 & 4 & 83 & 84 \\
\hline 21 & Sam A & 20 & 18 & 16 & 18 & 4 & 76 & 21 & 19 & 16 & 18 & 4 & 78 & 77 \\
\hline
\end{tabular}




\begin{tabular}{|c|c|c|c|c|c|c|c|c|c|c|c|c|c|c|}
\hline 22 & Sahraj R & 23 & 18 & 17 & 18 & 4 & 80 & 24 & 17 & 17 & 19 & 4 & 80 & 80 \\
\hline \multirow[t]{2}{*}{1} & 2 & 3 & 4 & 5 & 6 & 7 & 8 & 9 & 10 & 11 & 12 & 1 & 14 & 15 \\
\hline & & & & & & & & & & & & \multicolumn{3}{|l|}{3} \\
\hline 23 & Sigit & 21 & 17 & 17 & 18 & 3 & 76 & 20 & 18 & 17 & 19 & 4 & 78 & 77 \\
\hline 24 & Syamsul R & 22 & 18 & 17 & 19 & 4 & 80 & 22 & 19 & 18 & 19 & 4 & 82 & 81 \\
\hline 25 & Soleh d & 23 & 18 & 17 & 19 & 4 & 81 & 24 & 19 & 17 & 18 & 4 & 82 & 81 \\
\hline 26 & Tri W & 24 & 19 & 17 & 20 & 4 & 84 & 25 & 20 & 17 & 19 & 4 & 85 & 84 \\
\hline 27 & Widya & 22 & 18 & 17 & 16 & 3 & 77 & 21 & 17 & 17 & 20 & 4 & 79 & 78 \\
\hline 28 & Wiwit S & 22 & 19 & 17 & 20 & 4 & 82 & 21 & 20 & 17 & 19 & 4 & 81 & 81 \\
\hline 29 & Yahya W & 25 & 20 & 17 & 19 & 4 & 85 & 26 & 20 & 17 & 20 & 4 & 87 & 86 \\
\hline \multirow[t]{3}{*}{30} & Zahra M & 25 & 20 & 17 & 20 & 4 & 86 & 25 & 19 & 18 & 20 & 4 & 86 & 86 \\
\hline & Jumlah & & & & & & & & & & & & & 2461 \\
\hline & Nilai rata-ra & an & & & & & & & & & & & & 82,03 \\
\hline
\end{tabular}

Keterangan:

I : : Isi

Ol : Organisasi Isi

Kk : Kosakata

PB : Penggunaan Bahasa

M : Mekanisme

Berdasarkan tabel di atas diperoleh nilai rata-rata siswa pada pelaksanaan pretes kelas eksperimen, yaitu sebesar 73,06. Nilai tersebut merupakan hasil perhitungan jumlah nilai rata-rata sebesar 2193 dibagi jumlah siswa, yaitu 30 orang. Selain itu, dari tabel di atas juga diperoleh nilai rata-rata siswa pada pelaksanaan postes, yaitu sebesar 82,03 . Nilai tersebut diperoleh dari perhitungan nilai rata-rata siswa sebesar 2461 dibagi jumlah siswa, yaitu 30 orang.

Dari hasil perhitungan nilai rata-rata tersebut dapat diketahui bahwa nilai ratarata siswa ketika postes lebih besar dibandingkan dengan nilai rata-rata siswa ketika pretes. Hai ini terbukti dengan adanya kenaikan yang signifikan terhadap jumlah ratarata siswa, yaitu 73,06 menjadi 82,03. Berdasarkan rata-rata tersebut, maka diperoleh perbedaan (gain) antara nilai rata-rata pretes siswa dan nilai rata-rata postes siswa sebesar 8,93.

Perbedaan kenaikan nilai rata-rata tersebut belum dapat membuktikan bahwa metode sugesti-imajinatif efektif untuk pembelajaran menulis karangan deskripsi, kepastian keefektifan akan terlihat jika nilai tersebut sudah digunakan dalam perhitungan pembuktian hipotesis dengan menggunakan metode statistik.

Setelah melewati semua tahapan penelitian dapat terlihat bahwa metode sugestiimajinatif efektif meningkatkan kemampuan menulis deskriptif seperti penelitian terdahulu yang dilakukan oleh Huda, Muhammad Mishbakhul. (2019) dengan judul "Keefektifan Pembelajaran Menulis Cerita Pendek dengan Model Kreatif Produktif dan Model Sugesti Imajinasi Berdasarkan Kreativitas Verbal pada Peserta Didik Kelas XI 
SMK", yang juga memiliki hasil maksimal dan positif dalam meningkatkan kualitas kemampuan menulis cerita pendek siswa.

\section{KESIMPULAN}

Setelah melalui semua proses pelaksanaan Penelitian Tindakan Kelas (PTK) penulis mendapatkan kesimpulan akhir bahwa pelaksanaan pembelajaran melalui media kuis kahoot berkembang kearah positif sejak awal penerapannya. Hal tersebut ditunjukan melalui kemampuan mahasiswa dalam mengoperasikan kahoot dengan baik tanpa adanya kendala teknis berarti dari waktu ke waktu. Aplikasi kahoot mampu mengahadirkan suasana baru yang dinamis, atraktif, dan menyenangkan karena karakteristik berbasis teknologi permainan yang membuat mahasiswa menjadi lebih antusias dan tidak bosan dalam melakukan rutinitas pembelajaran daring selama masa pandemi ini. Karakteristik dari aplikasi kahoot yang dekat dengan keseharian mahasiswa saat ini karena berbasis teknologi dan internet juga turut memudahkan proses pembelajaran. Ketertarikan dan antusisas mahasiswa merupakan pemantik yang sangat baik dalam menerima transfer materi dari dosen. Bentuk media pembelajaran yang didesign dalam bentuk kuis mengehmbuskan atmosfir kompetitif yang baik sesame mahasiswa, karena pada dasarnya mahasiswa memiliki rasa ingin menang dan lebih baik dari yang lain, terlebih hasil pelaksanaan kuis dapat mereka lihat bersema-sama sebagai hasil akhir. Hasilnya semakin mahasiswa terbuka dan terinsipirasi semakin banyak pula pemahaman materi yang diperoleh, oleh karenanya secara signifikan kemampuan tata bahasa mereka meningkat melalui hasil belajar yang memuaskan sesuai dengan indikator capaian yang ditentukan dalam proses perencanaan di awal siklus.

Hal positif di atas tentulah dapat menjadikan aplikasi kuis berbasis teknologi kahoot sebagai alternative media pembelajaran dalam upaya meningkatkan kemampuan tata bahasa Inggris mahasiswa. Adapun penelitian ini dapat menjadi referensi di hari kemudian bagi peneliti yang hendak melakukan penelitian dengan tema serupa.

Secara keseluruhan, kemampuan menulis karangan deskripsi siswa melalui proses pembelajaran menggunakan metode sugesti-imajinatif dengan media gambar fotografi dapat meningkat. Hal ini terbukti dengan adanya kenaikan yang signifikan di kelas eksperimen. Hasil tersebut dapat dilihat dari rata-rata nilai pretes 73,06 menjadi nilai rata-rata postes 82,03 .

Hasil pengolahan angket diketahui bahwa respon siswa terhadap pembelajaran menulis karangan deskripsi melalui penerapan metode sugesti-imajinatif dengan media gambar fotografi sangat baik. Hal ini dibuktikan dengan jumlah presentase jawaban siswa terhadap pembelajaran menulis karangan deskripsi dengan menggunakan metode sugesti-imajinatif dengan media gambar fotografi. Dari hasil pehitungan angket, $100 \%$ siswa menjawab bahwa metode sugesti-imajinatif dengan media gambar fotografi yang diterapkan oleh guru pada proses pembelajaran menulis karangan deskripsi dapat menumbuhkan motivasi belajar siswa. Sama halnya dengan jumlah persentase sebelumya, $100 \%$ siswa menjawab bahwa metode ini dapat memudahkan siswa dalam menemukan ide. Sementara itu, 93,3\% siswa menjawab bahwa metode sugesti-imajinatif ini dapat memudahkan siswa untuk mengembangkan ide dengan bahasa yang baik dan benar sedangkan 6,7\% siswa menjawab bahwa metode ini tidak dapat mengembangkan ide dengan bahasa yang baik dan benar.

Berdasarkan pada simpulan di atas diharapkan metode sugesti-imajinatif dengan media gambar fotografi dalam pembelajaran menulis karangan deskripsi dapat menjadi masukan bagi para guru, khususnya bagi guru mata pelajaran Bahasa Indonesia untuk mengembangkan kemampuan dalam proses belajar mengajar terutama pembelajaran menulis karangan deskripsi. Dalam metode pembelajaran ini diharapkan guru dapat memotivasi dan menarik perhatian siswa dalam menemukan dan mengembangkan ide-idenya melalui proses melihat gambar yang diiringi musik. 
Pembelajaran menulis karangan deskripsi merupakan pembelajaran proses yang membutuhkan latihan secara berkesinambungan. Oleh karena itu, pendidik seharusnya memberikan latihan-latihan dan perbaikan untuk memperoleh hasil yang lebih baik.

Keaktifan siswa dalam pembelajaran terutama pembelajaran menulis karangan deskripsi perlu dikembangkan karena siswa yang belajar dengan aktif dapat memperoleh pengetahuan dan pengalaman yang dilakukan sendiri, berpikir kreatif, dan inovatif sehingga siswa dapat belajar lebih baik dan optimal.

Bagi para peneliti yang berniat mengembangkan metode sugesti-imajinatif dalam pembelajaran menulis hendaknya menggabungkan metode pembelajaran yang digunakan dalam penelitian ini dengan metode pembelajaran lain sehingga mampu memecahkan masalah yang dihadapi siswa dalam menulis terutama menulis karangan deskripsi

\section{DAFTAR RUJUKAN}

Arikunto, Suharsimi. (2006). Prosedur Penelitian Suatu Pendekatan Praktik. Jakarta: Rineka Cipta.

Daryanto. (2010). Media Pembelajaran. Yogyakarta: Gava Media.

Muhammad, Mishbakhul Huda. (2019).Keefektifan Pembelajaran Menulis Cerita Pendek Dengan Model Kreatif Produktif dan Model Sugesti Imajinasi Berdasarkan Kreativitas Verbal Padapeserta Didik Kelas Xi Smk. Thesis Universitas Negeri Malang. Semi, Atar.( 2007). Dasar-dasar Keterampilan Menulis. Bandung: Angkasa.

Subana. (2009). Strategi Belajar Mengajar Bahasa Indoesia.Bandung: Pustaka Setia. Sudjana, Nana dkk. (2005). Media Pengajaran. Bandung: Sinar Baru Algesindo.

Sugiyono. (2010). Statistik Untuk Pendidikan. Bandung: Alfabeta.

Syihabuddin. (2009). Evaluasi Pengajaran Bahasa Indonesia. Bandung: Pascasarjana UPI.

Tarigan, Henry Guntur. (2008). Menulis Sebagai Suatu Keterampilan Berbahasa. Bandung. Angkasa.

Tarigan, Henry Guntur. (2009). Metodelogi Pengajaran Bahasa. Bandung: Angkasa.

Zainurrahman. (2011). Menulis Dari Teori Hingga Praktik. Bandung: Alfabeta. 